\title{
Money as a social relation beyond the state
}

\section{A contribution to the institutionalist approach based on the Argentinian trueque}

Hadrien Saiag (IIAC, CNRS)

Submitted version $(01 / 03 / 2018)$

Note: This is the submitted version of Saiag Hadrien (2019) "Money as a social relation beyond the state: a contribution to the institutionalist approach based on the Argentinian trueque", The British Journal of Sociology 70(3): 969-996. Published by Wiley. The published article is available here: https://onlinelibrary.wiley.com/doi/10.1111/1468-4446.12610

\begin{abstract}
:
This paper provides a contribution to the institutionalist approach to money through ethnographic research carried out in two local currency systems in Argentina (known as trueque). It argues that Argentinian local currencies must be considered as monies in their own right even if they differ from state and bank issued currencies, because they can be understood as systems of evaluation and settlement of debts denominated in a specific unit of account (the crédito). Money is said to be an ambivalent social relation because in the two cases studied it mediates very different dynamics, exacerbating inequality in one context and promoting collective emancipation in another. This difference is due to the kind of political communities that the crédito tends to forge. In both Rosario and Poriajhu, the political community is defined by a set of values that legitimizes on-going monetary practices and institutions rather the State's coercion.
\end{abstract}

Keywords: money, debt, institutionalist approach, money plurality, Argentina

Number of words: 11577 


\section{Introduction}

Argentina's situation from the mid 1990s to the early 2000s constitutes an interesting challenge to theories of money. Similar to Russia during the 1990s (Woodruff 1999), Argentina was characterized by the cohabitation of multiple currencies, issued in a variety of ways. From 1991 to 2003, the national currency (peso) was tied to the USD. The new-born "convertibility regime" (Roig 2016) provided ephemeral economic stability and growth during its first years, but led to important cash shortages and deflation from 1998. This led to a severe social, economic and political crisis in 2001-2002. As the crisis worsened, more and more provincial governments issued their own fiscal currencies. Such currencies had re-emerged in the north-western provinces at the end of the last military dictatorship (1983), and by 2002 were being used in sixteen of the country's twenty-three provinces (Théret 2017). These currencies were usually seen as IOUs: they were issued to pay local government employees and suppliers, and accepted in settlement of provincial taxes, but they were also used as a means of payment among the population. In addition, from 1995 on, a wide spectrum of activists, churches, neighbourhood associations, and local politicians issued their own currencies 'from below'. This was known as trueque (literally 'barter'). These currencies usually consisted of paper monies (bills) denominated in their own unit of account (crédito), which tapped part of the informal urban economy. They were used to buy foodstuffs and other household goods at weekly market places referred to as feria, attended mostly by very poor women. These currencies reached a peak in the early 2000s before running into trouble in 2002, but were still in use in 2009, when the fieldwork on which this paper is based was being done. During the late 1990s and the early 2000s, the Argentinian working class juggled between pesos and créditos, while civil servants paid their expenses in provincial currencies, and the most well-off converted their savings in US dollar.

While medias extensively covered this situation by associating the proliferation of monies with the Argentina's crisis, economists and sociologists addressed it in terms of monetary plurality (i.e. the circulation of means of payment issued by distinct entities and denominated in specific units of account). On the one hand, mainstream economists interested in Argentina's monetary configuration had no problem considering créditos and provincial currencies as monies, because they are said to act as "mediums of exchange". They argued that the coexistence of several monies is not necessarily due to the crisis, but rather stems from individual's choice to hold various currencies, so as to maximize their utility according to each currency's transaction cost (Colatelli and Blackburn 2009) or inflation rate (Krause 2003). On the other hand, critics of this conception of 
money do not consider créditos and provincial currencies as monies in their own right because they merely act as "mediums of exchanges" in limited spheres of exchanges: for this reason, neoMarxists do not consider them as "universal equivalent" (Féliz 2004), while neo-Chartalists insist on the lack of a proper unit of account established by an authority that goes beyond inter-individual bonds (Ingham 2004: 165-174). Instead, for Féliz (2004), the use of créditos and provincial currencies is symptomatic of a crisis of the accumulation regime adopted since the last military dictatorship, which led to increasing social and monetary exclusion. For his part, Ingham (2004: 165-174) interprets Argentina's monetary situation as a monetary 'disorder' (p. 165) or 'anarchy' (p. 166) provoked by 'the endemic weakness of Argentina's monetary system' (p. 168). In Ingham's view, the Argentinian government's failure to conclude an alliance with its national bourgeoisie and effectively levy taxes to repay its national debt has rendered it incapable of producing a 'critical mass of tax and bound monetary flows [...] result[ing] in monetary anarchy in which heterogeneous forms of money coexists' (p. 174), and, by extension, the inability to impose a stable unit of account. Thus, Corragio, Feliz and Ingham's reflections focus on the crisis that the plurality of money reveals rather than on an analysis of the trueque or provincial currencies themselves. In this respect, their analysis reflects the tendency of neo-Marxian and neo-Chartalists to conceive monetary uniqueness as the norm, and its plurality as a symptom of crisis, as highlighted by Blanc et al (2017) (see for instance Wray 1998; Aglietta and Orléan 2002: 81, Orléan 2014: 113-124; Fine and Lapavistas 2000). Historians, on the other hand, underline that money plurality can be found in a variety of non-crisis contexts. (Helleiner 2003; Kuroda 2008).

In this paper, I argue that a detailed and ethnographic analysis of two cases of trueque (referred to as Rosario and Poriajhú) located on the outskirts of one of Argentina's industrial hubs enhances the institutionalist approach to money in two respects. Firstly, claiming the legacy of the founding authors of the institutionalist approach such as Keynes, Simmel, Commons and Polanyi, I argue that créditos must be considered monies in their own rights even if they differ from bank and stateissued credit currencies because they consist of a 'social relation' (Ingham 1996) of credit/debt denominated in a specific unit of account. Indeed, while transactions are often carried out in kind or using crédito bills whose fungibility is limited, they systematically involve the incurring, settling and evaluating of debts arising from transactions between trueque participants. Moreover, the fact that these transactions are carried out in crédito is of primary importance, because relative price expressed in créditos often differs widely from those expressed in peso. Secondly, considering créditos as monies sheds light on the micropolitics of the trueque, thereby revealing social and political dimensions of money that go beyond its relationship to the State. Indeed, the kind of social 
dynamics and political communities in which the crédito circulates differ widely between Rosario and Poriajhú. In Rosario, monetary transactions exacerbate structural inequalities because the most mobile trueque participants can take advantage of differences in price structures (expressed in pesos or in créditos), while in Poriajhú the keeping of a strict parity between the peso and the crédito ensures that the economic differences that prevail outside the trueque are not reproduced within it. Furthermore, it is argued that money can mediate such widely different social dynamics because créditos operate within specific and contrasted political communities. In Rosario, the trueque reinforces a dynamic of exclusion at work in Argentina since the mid 1970s because no attempt is made to challenge it through the creation of an alternative political community. On the contrary, the more egalitarian monetary relations observed in Poriajhú is explained by the fact that the strict parity between crédito and peso translates in the language of money a wider political project of emancipation of the poorest supported by an organization influenced by liberation theology. In each case, however, the political community is defined by a set of values that legitimizes on-going monetary practices and institutions in the place of State's coercion.

This paper is structured as follows. Section one introduces the trueque and the research method. Section two presents the evidence that créditos should be considered as monies in their own rights. Section three argues that money mediates highly contrasted social dynamics in Rosario and Poriajhú, depending on the crédito/peso price ratio that prevails. Section four interprets this finding by analysing the contrasted relations of each crédito to the political community in which it is inserted, based on a reconsideration of Ingham's understanding of 'authority'.

\section{Context and method}

The term trueque refers to a wide variety of experiences of issuing paper money (bills) denominated in their own unit of account (crédito - Image 1), which taps into part of the urban informal economy. Although trueque systems are highly dependent on the wider economic context, their constant transformations have given rise to a complex phenomena, which should not reduced to a reaction to the Argentinian crisis of 2001-2002. Trueque systems were launched in 1995 in the southern suburbs of Buenos Aires by three environmental activists. At the beginning, they consisted of small-scale systems of 'multilateral compensation of credit and debt' (Servet 1999: 183) similar to Local Exchange and Trading Systems: transactions took place at ferias (market-places in which transactions are carried out in créditos) organized in the founders' garage. At the close of the feria, each participant's account, denominated in créditos, was debited or credited based on their 
purchases and sales, and registered in a computerized system. The trueque grew sharply until the early 2000's, thanks to the increasing participation of impoverished middle-class women whose husbands had lost their jobs as a result of labour flexibilization policies in the 1990s (Kessler 1999). As a result, ferias multiplied, first around Buenos Aires and then throughout the whole country. In late 1996, bills denominated in crédito replaced the computerized debt compensation system, considered too time-consuming to update. They were issued by local commissions formed by the most active participants of each feria, and could only be used to settle transactions inside that feria. Most of the time, 50 créditos were assigned to each new participant (they were expected to give back this sum if they stopped attending the trueque altogether, but they almost never did).

In 1998 trueque participants decided to adopt a federative structure known as Red Global de Trueque (for Global Trueque Network - see REF ANONYM 2013). Ferias were grouped together on a geographical basis in different "zones": Capital (city of Buenos Aires), Southern, Western and Northern suburbs of Buenos Aires' (new zones were created when the trueque expanded beyond the province of Buenos Aires). Each zone could establish its own rules for money issuing through a commission managed by the feria's coordinators (for example, the amount of créditos per new participant could vary from zone to zone, and some of them decided to issue crédito in order to pay their cleaning staff). However, to be part of the network, each zone had to respect a maximum ratio of créditos per participant established by the 'Interzonal Commission' (composed of representatives of each zone). As a result, each zone issued its own set of bills, clearly distinguishable from other zones' bills (in colour, motif, shape and size), but each locally issued bill was accepted throughout the network, regardless of its original zone.

The RGT did not survive the transformations that the trueque underwent in the early 2000s, when Argentina was well into one of the deepest crisis in its history, due to the parity between the Argentinian peso and the US dollar established in 1991. From 1998 to 2002, the amount of pesos in circulation reduced sharply, as a result of Brazil's devaluation in 1998 (Argentina's first commercial partner at the time) and of huge capital outflows in 2001 that led to the imposition of severe limits on cash withdrawals. The result was a drastically impoverished Argentinian's middle and working classes. By mid 2002, participation in trueque systems reached its zenith (with an estimated two million participants - Ould-Ahmed 2010), thanks to the huge influx of slum dwellers. However, the trueque suffered a severe hyperinflation crisis from June to September 2002, partly due to the growing discrepancy between the amount of crédito in circulation and participants' productive capacity, as well as conflicts related to the monetary reforms that were trying to restore 
trust in local currencies (REF ANONYM 2013: 75-86). The crisis led to a drop in the number of trueque participants and the dissolving of the RGT: the coordinators of local ferias stopped attending the zonal and interzonal commissions.

After this crisis, the trueque partially recovered at local levels. Once Argentina abandoned the pesodollar parity in 2002, GDP and employment rose sharply, and income inequality diminished (Beccaria, Maurizio and Vázquez 2015). While participation in trueque systems also diminished compared to the early 2000 s, they still attracted members of the urban working class who lacked stable jobs. Most of them were domestic migrants who came to the cities starting in the mid 1970s, and by the early 2000s belonged to the urban sub-proletariat who were often paid in kind for daily contingent work (see section 3). However, some of the better-off working class also attended the ferias. Transactions mostly involved household commodities (used clothes, groceries, vegetables, cleaning products, sewing and small decoration items) in often very small amounts, if the small denominations of bills are any indication. Créditos were often issued by the people founded the trueque in the area (and often participated in the zone's crédito commission), but their circulation was restricted to a specific urban agglomeration encompassing the surviving ferias (Orzi 2012).

This paper is based on two ethnographic field studies carried out from July to November 2007 and from August to December 2009, in two different settings: Rosario (the third most populated city in Argentina, located $400 \mathrm{~km}$ from Buenos Aires) and Capitán Bermúdez (a small town, part of Rosario's northern suburbs). Information was collected through detailed observation of monetary practices that took place in the ferias (I attended them on a systematic basis, as a buyer, seller and observer), and eighteen in-depth interviews with trueque participants, in order to reconstruct the rationale of their household's budget (especially the linkages between their participation in the trueque and other income-generating household activities). Both settings share a common history, as they belonged to the same zone at the time of the RGT (the South of the Santa Fe's province). However, they diverged sharply. When the RGT collapsed, the coordinators of the remaining ferias located in Rosario (mainly in its western, working-class periphery) decided to carry on transactions using the créditos issued by the South of Santa Fe's zone. The coordinators delegated the task of issuing the new crédito bills to the nurse who first implemented the trueque in the Santa $\mathrm{Fe}$ province (she contracted a printer to protect the bills from falsification and put new bills of higher denomination into circulation to face growing inflation). In addition, they stopped allocating 50 créditos to each new participant: henceforth, to access crédito it became necessary either to sell one's commodity or to pay 10 pesos to one of the feria's coordinators to receive 8,000 newly issued 
créditos. When the field work was carried out, transactions took place in three ferias, which attracted between twenty and one hundred people: three times a week in a wasteland known as 'el campito', twice a week in Alem square, ${ }^{\mathrm{i}}$, and twice a week at a neighbourhood association, St Cristobal. Coordinators in place since the early 2000s organized the ferias. His or her tasks consisted of ensuring the cleanliness of the market place, preventing conflicts, changing peso to créditos on demand and, in St Cristobal, making sure that people could participate in the feria on equal footing (for this, it was forbidden to sell while people were queuing to enter the neighbourhood association, but participants often broke that rule). However, no formal organization governed the trueque in Rosario, beyond interpersonal ties between the bills' issuers and each feria's coordinator.

This low degree of institutionalization contrasted starkly with the system in Capitán Bermúdez. In late 2002, the ferias there decided to issue their own crédito bills, to gain greater control over their crédito. From that moment forward, créditos were issued by a non-governmental organization, Poriajhú, influenced by the liberation theology and whose aim is 'the liberation of the poorest', (Poriajhú mean ‘the poor' in Guarani). Poriajhú already coordinated the ferias located in Rosario’s northern periphery in the early 2000s, but it was most well-known for the literacy and popular education workshops it organised since the end of the last dictatorship, in 1983. Poriajhú's activities also include radio programmes, school tutoring and the promotion of native languages in Amerindian-populated slums. Economic development activities were incorporated in the late 1990s, as a reaction to the economic crisis: first, cooking, sewing and craft workshops were proposed to women in order to provide an alternative source of income; then the trueque aimed at providing a space in which people could access basic household commodities while avoiding the usual mechanisms of exploitation. (Since the late 2000s, Poriajhú also provides governmental microcredits to allow small shopkeepers to manage their working capital). From 2003 to 2007, each feria in Capitán Bermúdez issued its own crédito bills, only valid in that feria. However, in November 2007, participants decided to issue a new crédito bills, valid in all the ferias of the area. At that point, newly issued crédito bills were then allocated to each new participant, according to the commodities offered: those selling items produced themselves received between five and eight créditos, in comparison to 2.5 to four créditos for those doing resale. Crédito bills circulated during three ferias, each attracting ten to forty people, most of whom also benefited from microcredit (in pesos) through the governmental program locally administrated by Poriajhú. 


\section{Créditos as monies in their own rights}

Questioning the theory of money based on local currencies may seem surprising, as local currencies are often seen as lacking some definitional characteristics of money: they would be restricted to "networks of exchange transactions" (Ingham 2002: 139) because they are too localized and of limited fungibility, and 'no more than a convenient medium of exchange' and, therefore, lacking a proper unit of account (Ingham 2004: 184). I argue rather that créditos must be considered monies in their own right rather than 'quasi' or 'surrogate monies' because the trueque is constituted by multiples systems of evaluation and settlement of debts. The quality of moneyness does not lie in specific qualities of monetary instruments (such as its fungibility), but in the fact that they are used to quantify and settle debts. Moreover, these monetary systems are based on a specific unit of account (the crédito) that does not shadow the peso: indeed, the price system denominated in crédito must be incorporated by the trueque participants, as price lists differ widely depending on whether they are denominated in crédito or in peso.

The trueque: a system of evaluation and settlement of debts

Instruments used to carry out transactions in the trueque may differ from what is conventionally understood as money. To conceive them as such, it is necessary to distinguish between money as a concept and monetary practices and instruments: as an abstract system of evaluation and settlement of debt, money is defined by its 'generic properties' of account and settlement (Ingham 2002: 124; Théret 2008: 819-823), while instruments and practices are said to be 'monetary' when they allow debt to be evaluated and settled in concrete transactions (Blanc 2006 - see also REF ANONYM 2014). By so doing, it is possible to label transactions that would otherwise be considered in kind as as "monetary". In other words, monetary instruments are defined by the way they are used rather than by their intrinsic qualities.

In Rosario and Poriajhú, transactions are carried out in two main ways. The first consists of using bills denominated in créditos: the seller transfers his commodity to the buyer, who, in turn, transfers the equivalent of the commodity's nominal value in créditos. Through this process, debt is incurred and settled almost instantaneously (see also Ingham 2006: 26). Créditos are not necessarily transferred to the seller during the feria, however: when cotraders have already transacted before, sales are often carried out on credit. In this case, a claim is noted down in the créditor's notebook (while the debtor notes the debt in his own notebook), and the debt is settled during the next ferias, 
through repayment in créditos or in kind. (In other words, there is no multilateral system of debt compensation).

The second kind of transaction, also used very often, is called 'trueque directo'. The literal translation of this expression, 'direct barter', reveals that the trueque participants consider it a purely bilateral transaction: goods change hands against other goods on the basis of their use value, and no money is involved. The situation is more complex, however, as illustrated by a transaction between Eleonora, Stefani and Luis (Table I). Luis works in one of Rosario's wholesale fruit and vegetable markets. The fruit and vegetable produce he receives exceeds his household's consumption because Luis is partly paid in-kind. He therefore sells the surplus in créditos. As soon as he arrives at 'el campito', he seeks out Eleonora and Stefani, with whom he has a long-term commercial relationship. Eleonora selects the fruits and vegetables she wants, and Luis does likewise with Eleonora's products: salt, sugar and soap. Luis then returns to his feria stand. Next, Luis and Eleonora separately assess the value of the goods they have just exchanged, in créditos (Eleonora calculating the goods she has transferred to Luis, and vice versa). Luis then returns to Eleonora and they compare accounts, establishing that the value of the goods Luis transferred to Eleonora exceeds those Eleonora transferred to Luis by 3500 créditos (transactions are almost always imbalanced). To settle the accounts, Eleonora transfers 1 kilogram of sugar to Luis with an evaluated value of 3500 créditos. This operation is then carried out in the same way between Stefani and Luis.

\section{Insert Table I here}

Admittedly, both crédito bills and trueque directo differ from conventional credit monies in two ways. Firstly, they can hardly be considered as a promise to repay the issuer's debt. This is obvious for the trueque directo but more ambiguous for the crédito bills, because while no payment to the issuing authority is required in either Rosario or Poriajhu, participants are supposed to reimburse Poriajhu the créditos received upon joining their first feria when they definitively withdraw from Poriajhu's trueque. In this case crédito bills could be seen as a kind of "life debt", but in practice, participants do not give the créditos back. Secondly, both trueque directo and crédito bills can be seen as forms of immediate settlement of debt: they differ from credit relationships in the sense that the bilateral relationships between specific debtors and creditors do not extend over time (Carruthers 2005).

So while trueque directo and use of credito bills may not embody characteristics of convention credit monies, they still must be considered monetary practices. By so doing, they introduce a third 
party to bilateral transactions, as argued by institutionnalist approaches to money. The case of paper money follows a classical line of argumentation: because all the trueque participants accept crédito bills as payment, bills constitute a claim on the microsociety they form (Simmel). This is less intuitive for the trueque directo. Indeed, there is no guarantee that commodities received in a transaction will be accepted as payment by another seller: Therefore, commodities are not a "claim on society". However, trueque directo still introduces a relation to the microsociety formed by the crédito users, because debts are not evaluated in commodities, but in crédito. Moreover, the fact that people express their prices in crédito is of primary importance, as trueque participants usually take the price list for granted: in other words, prices are not affected by any specific relationship that the seller and the buyer could establish. In addition, following Commons (2005 [1934], chapter 9) trueque directo must be considered as a monetary transaction because the fact that Eleonora transfers 1 kilogram of sugar to Luis in order to settle their unbalanced accounts shows that commodity transfers result in incurring and settling debts: the first commodity transfer incurs a debt Eleonora owes to Luis; this debt is settled when the former transfers her commodities to the latter. That is why commodities used for settling the debt in the trueque directo must be seen as means of payment whose fungibility is limited to a specific transaction (see also Ould-Ahmed 2003 and Aglietta and Orléan 2002: 69-74 for a similar argument), rather than a "non-monetary means of payment" (Woodruff 1999: 147).

\section{The crédito, a unit of account clearly distinct from the peso}

The fact that the trueque qualifies as money would be unimportant if transactions carried out in its realms mimicked those in the peso sphere. In this case, people would merely set prices using a conversion rate between the peso and the crédito, as argued by Ould-Ahmed:

'This crédito / peso relation was indeed present in the minds of all the participants [...]. When asked how they set the price of a good, the participants replied that it was based on its price in the official currency, which they then converted using the rule of crédito / peso equivalence in force at the time [...]. From a theoretical viewpoint, the official currency remained the only truly relevant unit of account within this micro-monetary system, and the crédito was no more than a subordinate unit of account.' (Ould-Ahmed 2010: 1356 emphasis added)

Yet, this assertion is problematic because it does not fit with ethnographical records. Indeed, while a conversation rate is sometimes mentioned to new participants, it is of no use in concrete 
transactions that require basic manipulations of this rate. I observed that people display very different implicit peso/crédito conversion rates when they refer to prices expressed in peso and in crédito. Trueque participants almost systematically incorporate the way prices are set in crédito without referring to the peso in order to carry out their transactions: when this is not the case, they lose the sense of crédito price-making and are likely to be defrauded ${ }^{\mathrm{ii}}$.

The main reason why people do not merely convert prices from pesos to créditos is that both nominal and relative prices (i.e. price ratios) vary between the crédito and peso spheres. In order to explain this, it is necessary to have a detailed look at the implicit conversion rates in effect in various trueque systems. In a nutshell, Ould-Ahmed suggests that the same implicit 'conversion rate' applies to all commodities offered in the trueque: but if this were the case, it would be possible to translate a price structure from pesos to créditos through a simple multiplication. Data obtained by Drelon (2009), Gómez (2015) and myself show that this hypothesis is irrelevant: in many ferias, this rate varies widely from one commodity to another. Tables III to V allow this phenomenon to be quantified. iii This is based on a detailed price list established by Gómez in 2004, Drelon in 2006, and myself in 2009 (Tables II, IV and V). In the ferias studied by Gómez, transactions take place on the basis of the same crédito, as they are all part of the Red Global de Trueque. Drelon's situation is more complex. In Roca Negra, and la Aceitera, transactions are based only on crédito bills issued by the Red Global de Trueque, while in Villa A Brown a wide variety of créditos are used (most of which are not used any more in their original networks). Quinta del Pato is the name of a farm located $60 \mathrm{~km}$ away from Buenos Aires, in which 'Bolivian clandestine workers' indebted to the farm owner sell fruit and vegetables they produce themselves (Drelon 2009: 163). In this case, transactions are carried out in eggs, both as a unit of account and means of settlement ${ }^{\text {iv }}$. Table IV and the last column of Table III display the implicit conversion rates (or price ratios) in ferias in which prices are denominated RGT créditos (Roca Negra, Aceitera and Cartel IX). The first three columns of Table III present a comparison of implicit conversion rates in Roca Negra, Aceitera, Quita del Pato and Villa A. Brown. In this case, however, each price ratio refers to prices expressed in different units of accounts (RGT créditos, used créditos, eggs and peso - see Box one). Table V shows the same kind of data, collected in Rosario. (The case of Poriajhú, in which the 'conversion rate' hypothesis applies, is analysed later).

Insert here Tables II to V 
The statistics displayed at the bottom of Tables III to V show two main results. Firstly, implicit conversion rates vary widely from one commodity to another when prices are denominated in different units of account, as shown by the line 'standard-deviation / means' (Tables III and V). In this case, then, the hypothesis of a unique 'conversion rate' must be rejected. Secondly, price ratios seem to vary much less when prices are denominated in the same unit of account, as in Roca Negra, La Aceitera and Cartel IX (Table IV and last column of Table III). Taken together, these results show that the 'relative price' of commodities depends on the unit of account in which transactions are denominated, and that only nominal prices seem to be affected when transactions occur in different ferias in which transactions are denominated in the same unit of account.

This is of key importance. Admittedly, the fact that price ratios vary according to the monetary sphere in which transactions take place should not surprise institutionalists and sociologists interested in money: the differences between price lists reflect the fact that each monetary sphere reflects specific social relations. That is why it is widely accepted that prices differ from one country to another. However, the novelty of my argument lies in the fact that relative prices can differ from one unit of account to the other even if they are both used in the same political entity. This means that the various créditos in use and the Argentinian peso not only differ as regards to the degree of fungibility of their means of payment, as Ingham would argue (2004: 76-77): they also convey their own expressions of value. This is why they represent monetary spheres that are relatively autonomous from the national unit of account. It is also why the trueque fully qualifies as money.

This, in turn, leads to two reciprocal theoretical considerations concerning money and value. First, the expression 'standard of value' to refer to money's role as a unit of account should be avoided. Indeed, it suggests that money merely 'measures' a value that exists in a homogeneous form, like kilograms and meters measure weights and distances. Yet, as it has been argued, value can be expressed in multiple ways, as each monetary sphere conveys its own price list. That is why, I prefer using the expression "evaluation of debt" in order to highlight that the evaluation of debts incurred in transactions involves both a qualitative aspect (in what context is the transaction taking place?) and a quantitative one (how much A owes B). Second, the fact that value can be expressed in multiple ways also means that the units of account themselves are subject to plural evaluations. Indeed, if the value of a commodity expressed in units of account varies according to the monetary sphere in which transactions take place, then the purchasing power of the unit of account (expressed in terms of the amount of commodities it can buy) also varies from one monetary sphere to the 
other. This means that one peso can buy much more than one crédito and, most importantly, that the the basket of commodities a peso can buy differs widely from the basket that $x$ créditos can buy. Taken together, these theoretical considerations show that transactions carried out in the realm of the trueque forge simultaneously the value of the traded commodities and the crédito's purchasing power.

This reflexion sheds a new light on Poriajhú's case. To my knowledge, it is the only example where the hypothesis of a 'conversion rate' between the peso and the crédito is valid, since it successfully maintains the parity between these currencies for all commodities. Poriajhu established this parity in 2007 by entirely recasting its monetary system. However, what is remarkable is that it managed to maintain parity over time (moreover, testimonies collected in the field work indicate that even during the trueque crisis in 2002 prices remained relatively stable). If we consider money as a system of debt evaluation, Poriajhú's parity between peso and crédito is an exception as regards other trueque systems, rather than the confirmation of the 'conversion rates' theoretical premise. As such, it is important to question the implications of this exception, and the conditions that explain it.

\section{Money and power: from disjuncture to the ambivalent social relation of money}

A more detailed look at the transactions carried out in Poriajhú and Rosario shows that the way debts are evaluated has deep sociological implications. Indeed, it plays a key role in power relations among the trueque participants: the fact that price structures differ from one monetary sphere to the other makes room for gain through arbitrage (similar to what happens in financial speculation), but not all the participants can take advantage of it. This dynamic can be understood by using Jane Guyer's concept of 'disjuncture' (2004), which states that monetary evaluations can involve discontinuities between different value scales. In Rosario, there is indeed a discontinuity between price structures expressed in pesos and créditos, as price lists cannot be reduced to a common one through divisions or multiplications. Because of this, those who juggle skilfully between the various monetary spheres can gain small profits: by so doing, they link 'disjunctive value registers' through 'conversions' (Guyer 2004: 51). A crucial task, therefore, is to understand the sociological implications of disjuncture. It is argued that money mediates very different kinds of social dynamics in Rosario and Poriajhú, precisely because disjuncture happens in the former but not in the latter: while disjuncture tends to reinforce social stratification in Rosario, maintaining parity between peso and crédito leads to a much more egalitarian social relationship in Poriajhú. 
In Rosario, the room for profit through conversions is shown in Table V. Two crucial observations can be made. First, as mentioned above, the magnitude of disjuncture between the peso and the crédito evaluations can be seen by the wide variation of the crédito/peso ratio between commodities (its standard deviation/means is one of the highest). Second, despite the wide variation of crédito/peso ratios among the same group of commodities, the mean of the crédito/peso ratios is much higher concerning non-perishables (mainly food) than products derived from social assistance in-kind subsidies, vegetables and second-hand clothes. Yet, non-perishable food necessarily has to be imported from the peso sphere. Therefore, multiple opportunities of gain arise at the interface between the peso and the crédito sphere. However, not all the trueque participants can equally take advantage of this disjuncture. To show this, it is necessary to understand how the trueque is linked to the peso sphere, through household economies.

Three kinds of crédito / peso conversions can be observed in Rosario. Firstly, gains can be due to people's (relatively comfortable) income in peso. Eleonora, her daughter Angela and her friend Stefani are a good example of this. Their household budgets and trueque usage have certain common points. Firstly, their truque participation is not primarily motivated by economic necessity; they have relatively easy access to the peso. In Stefani's case, this is chiefly due to her husband's income (he owns a small road haulage contracting business, a car wash in a residential neighbourhood, and sells part of his fishing catches from the Paraná River). Her daughter is meanwhile an employee in a mutual insurance company. Stefani also has direct access to the peso thanks to the various services she offers to elderly people in her neighbourhood (e.g. taking them to the doctors or the pharmacy; helping them with administrative tasks, etc.). Angela and Eleonora meanwhile run rather distinctive small businesses ('microemprendimientos') for which there is a strong demand (chiropody and massage therapy in Eleonora's case; catering, waxing and make-up services in Angela's).

Their favourable access to the peso allows them to take advantage of the heterogeneous crédito/peso ratios, as exemplified by the transaction between Luis, Eleonora and Stefani (Table I). Note that Luis offers fruits and vegetable to both Eleonora and Stefani, and who in return give him nonperishables previously bought in pesos from a wholesaler. Thus, the crédito/peso ratio of commodities offered by Eleonora and Stefani is much higher than that of commodities offered by Luis (Table I), representing a source of profit for the couple. In other words, Eleonora and Stefani received more fruit and vegetables than they would have had the debts been evaluated in pesos. 
Juggling between the peso and crédito as described above is not common, however: in Rosario, the people who participate in the trueque are mainly those who depend on it for daily food. These participants do not have easy access to the peso, but have activities that lend themselves to juggling monetary spheres, and allow them to take advantage of the disjuncture. Moreover, even when their household incomes are partly denominated in pesos, their budgets show strong interdependency between the two spheres: accessing pesos depends on transactions in créditos.

A couple called Celina and Jorge exemplify this. The only way they access pesos, outside the trueque, is by Joge selling garbage-picked cardboard. This activity generates very little money, however $(0.30 \$ / \mathrm{Kg}$, while a bus ticket costs $1.75 \$)$. Most of the couple's income results from conversions between crédito and peso, in which Jorge's job in Celina's mother's small general store (kiosko) plays a key role. The kiosko is jointly managed by Jorge and Celina's mother, but income generated by the sales of Jorge's commodities goes to him, and vice-versa. Jorge's work in the kiosko dovetails with the couple's participation in Rosario's ferias. Apart from second-hand and new clothing (unsold items from the small clothing business that Célina's sister runs), they also offer perfumes and aerosol sprays (deodorants, mosquito repellents, etc.) salvaged from the rubbish depot of the firm producing them. At the trueque, Celina is in charge of the clothes and seeks out all kinds of food (yoghurt, pasta, rice, fruit, vegetables, canned food, various sauces, etc.). Her husband is in charge of what he describes as the 'transformation' of aerosol sprays and perfumes into food. In this way, peso and crédito are juggled through on-going return trips between the trueque and their kiosko. Two examples illustrate this. Firstly, Jorge buys three soaps from a supermarket at 1.40 pesos each, and then sells them at the trueque for 3500 créditos apiece. With 3000 of the 3500 créditos, he buys three sponges (at 1000 créditos each), and sells them for two pesos apiece in the kiosko. He explains: 'from 1.40 pesos I get 6. And I still have 500 créditos left!' With the income generated by selling the sponges, he buys an aerosol with missing pieces for 3 pesos. With the pieces he collects, he repairs and sells the aerosol for 15 pesos in the kiosko. This crédito / peso juggling is also useful for 'multiplying' crédito (in Jorge's terms), as the following transactions highlight. Firstly, Jorge buys some biscuits for 2000 créditos. In the kiosko, he divides these biscuits between two boxes, selling them at 1.8 pesos per piece. With 1.50 peso of the 3.60 pesos he buys a bottle of vinegar, which he then sells for 4000 créditos in the trueque. Such juggling practices are more complex than those carried out by Stefani and Angela, because they are based on multiple, rather than simple, conversions from peso to crédito. They are also clearly profitable for the couple: Celina estimates the value of the food obtained at each feria to be worth around 70 pesos (or 560 
pesos per month -2 ferias per week), and this does not include the conversions made through the kiosko.

Those who are not in a position to juggle between crédito and peso constitute a third group. Because they do not connect their activity in the trueque with other income generating activities, they cannot take advantage of disjuncture. Take the example of Andrea. She lives with her partner, Esteban, and their child in a poor neighbourhood of Rosario. She only brings second-hand clothes to the St Christobal trueque, which are either no longer used by the household, or donations from relatives. Some clothes are also given to Esteban as part payment for daily contingent labour. Using the créditos they earn through these sales, Andrea mostly acquires other second-hand clothes and second-hand domestic products (curtains, mosquito repellent, cheese graters, etc.). Due to the very low sale price of second-hand clothes in relation to other products (Table V), she can only occasionally, and in restricted circumstances, obtain groceries (potatoes, apple, oil, flour, milk, pasta, etc.). The couple's access to the peso is also limited. Esteban's only income in peso comes from menial day labour (painting, repair work, etc.), which amount to only a few hours per week. He is sometimes paid in pesos, sometimes in building materials (for his house extension), and other times in second-hand clothing. Meanwhile Andrea cleans the toilets at a factory next to her house for two hours each Saturday. The couple's main income in pesos comes from washing cars, which they do in front of their house (having 'equipped' their garden for the job). However, income from this activity is highly irregular and relatively low (approximately 510 pesos per month). Therefore, the couple meets the majority of the household's food needs by juggling several sources of poverty relief aid. This comes from a neighbourhood association (dry milk), the Rosario municipality (for bolsón - oil, maté, sugar, salt, pasta, rice, etc.), and from the Church (for canned tuna, canned meat, sugar, maté). These resources are critical as they are the only regular influx of foodstuffs for the household. Even so, the couple's economic situation remains precarious, as expressed by their chronic indebtedness due to their irregular income.

In Rosario, therefore, the trueque stems from and reinforces a structurally unequal access to money, as those who benefit from disjuncture do so only because others have limited access to the peso, and must use the trueque to turn in-kind payments into money.

The situation is very different in Poriajhú. Admittedly, conversions from peso to crédito are also observed. However, no gain is derived from money juggling, because there is no disjuncture between peso and crédito evaluations. Indeed, Poriajhú successfully maintained the parity between 
peso and crédito for all commodities from 2007 to 2009. This is surprising, given the fact that trueque participants are even more diverse than in Rosario: they include small shopkeepers, women who run home-based sewing shops or home-based services relatively well-remunerated in pesos, small clothing sellers who get by thanks to microcredit programs, street vendors, as well as marginalized people relegated to daily contingent work. This success is due to the efforts deployed by the woman who first implemented the trueque in Capitan Bermudez, and who embodies Poriajhú's political project through her personal history, Marita. ${ }^{v}$ Her discourse includes a strong emphasis on the need to maintain the peso/crédito parity: while she may not be aware of the mechanisms mentioned above, she conceives this parity as a necessary condition to avoid exploitation in the trueque. Because of this, conversions from crédito to peso hardly ever happen. Rather, the crédito sphere offers an alternative commercialization channel for commodities that have not managed to be sold in pesos. (For instance, unsold food products prepared to be sold in pesos for a specific event, are usually sold off in crédito after the event. Likewise, home-based sewing shops complement their sales in pesos by selling in créditos at ferias). Thus, social stratification does not emerge at the interfaces between the peso and the crédito spheres, because gains do not depend on the ability of particular social group to juggle these monies. Therefore, ferias consist of a singular universe, where prevailing social inequalities are not reproduced and monetary rules are uncontested.

Both Rosario and Poriajhú highlight the complex relations that prevail between money and social relations. On the one hand, they show that social relationships that prevail outside the trueque deeply influence the monetary practices that take place in its realm. In both cases, the trueque is submerged in an already stratified and deeply unequal society. In Poriajhú, the trueque can promote less unequal social relationships because it is supported by a social organization whose action goes beyond monetary issues. In Rosario, the absence of this kind of organization explains why the trueque does not challenge the existing social hierarchies. In a way, therefore, monetary practices reflect the context in which they are inserted. But these cases also highlight money's transformative power, because the trueque affects the social relations that prevail in Rosario's popular economy. In Rosario, the unequal gains due to conversions between disjunctive value scales exacerbate the existing structural social stratifications. By the same token, the equality promoted by Poriajhú is effective (to some extent) precisely because it translates into a less unequal access to money: if it were not the case, attempts to transform social relations would come to nought. Hence money's ambivalence as regards to the social relations it promotes. 


\section{A relation to political communities beyond the State}

I would argue that to understand the kind of social dynamics mediated by the trueque, it is necessary to investigate money's role in the construction of political communities. However, the political community to which money refers should not necessarily be assimilated to the State's capacity to impose effective tax obligations, as it is usually conceived by sociological and institutionnalist approaches to money (Ingham 2004; Wray 1998 ${ }^{\mathrm{vi}}$ ). Indeed, a detailed look at Poriajhú and Rosario show that money can refer to political communities other than the State, if one critically considers the concept of authority. In Ingham's view, the political community is assimilated with the State because he conceives authority as the State's coercive power:

'Establishing the promise requires "authority", which ultimately rests on coercion [...]. In short, the monopolistic imposition of a money of account, and a refusal to accept any other than the approved credit tokens of the issuer, go hand in hand with monopolization of physical force' (Ingham 2004: 76 - emphasis added).

I would agree with Aglietta et al (1998) that authority and power should be distinguished:

'Authority is a complex of collective values, in the name of which the coherence of a society is affirmed and maintained. Norms of individual behaviours originate in those values. It is said that authority subordinates power in value. Power is a relationship of domination based on the possession of means, enabling some individuals to dictate the conduct of others' (Aglietta et. al. 1998: 11).

This distinction between power and authority is useful in the case of the trueque for two reasons. Firstly, if authority is a set of values embodied in local institutions, then it is not necessarily restricted to the national level. Secondly, and most importantly, this distinction allows one to consider the relations between money and political communities in a different way, through the question of money's legitimacy. Indeed, legitimacy does not lie with the State's power to impose its conception of money to society, as in Ingham's view. Rather, to be considered legitimate, monetary uses and institutions must conform to the values that define a particular political community ${ }^{\text {vii }}$.

On this basis, I argue that the social dynamics mediated by money in Rosario and Poriajhú vary so widely because their crédito emerges from different kinds of political communities with distinct histories. In each case, this relation to the political community is crystallized in the crédito/peso relationship. In Rosario, the fact that the price structure expressed in crédito differs from the peso does not reflect any attempt to transform the social relations that prevail in the peso sphere. On the contrary, as the previous section argued, this disjunction between value scales tends to exacerbate 
inequalities among the trueque participants. Trueque participants even seem unaware of this, because the exploitative relationships that define their existence appear almost natural. As a consequence, Rosario's trueque reinforces the dynamic of exclusion engendered by economic policies implemented in Argentina since the mid 1970s (and exacerbated during the 1990s), characterized by growing income inequalities, privatizations, deindustrialization and the rise of unprotected forms of employment (Svampa 2005). Therefore, it is not a surprise that even when tension around monetary practices arises in the ferias, coordinators never refer to any political community that would substantially differ from the national one in order to legitimize their view ${ }^{\text {viii }}$. This is because in Rosario, the trueque does not enjoy any 'ethical' foundation upon which unequal power relations can be contained.

By contrast, in Poriajhú the maintaining of a strict parity between the peso and the crédito reflects a specific political community, which explicitly tackles the issue of the working class' marginalization. In this respect, the difference with Rosario does not lie in the instruments used to control prices expressed in crédito (both cases previously used compulsory price lists for groceries and in both cases there is an official crédito/peso ratio on the basis of which prices should be set), but in these instruments' effectiveness: in Poriajhú, this parity has been maintained because it is considered legitimate, as it translates a wider political project into the language of money. Admittedly, this project may not appear coherent on the surface, given the diversity of activities carried on (see Section 1). However, the woman who embodies authority and the principle of trust in Poriajhú has a very unified vision:

'Marita: Poriajhú's goal, its mission, is to create participatory spaces for the people [pueblo, meaning close to "working class"], in order to proclaim and maintain its role as protagonist in the transformations of reality coming from critical education [educación popular] [...] All of the actions we carry out [...] have to pass through the quality control of this mission [...]. If not, what should we change in our practices in order for it to be the case?' (Interview with Marita, 12/2009)

In other words, Poriajhú's political community stems from its efforts to emancipate the poorest, based on a vision of social justice inspired by liberation theology. This community is taking place at the local scale of Poriajhú's means, but its aim of social transformation is much wider: to a significant degree, this political project brings an alternative to the subproletariat's on-going social marginalization, based on its inclusion as a collective subject.

In Poriajhú, the crédito participates in building such a political community in several ways. Firstly, the crédito/peso parity for each commodity allows the prevailing social inequalities not to be reproduced in the realm of the trueque, so that Poriajhú's political project can translate into 
practice. Secondly, the crédito also helps perpetuate the political community that Poriajhú aims to construct through a process Aglietta (1988) defined as a 'symbolic substitution', through which money takes on attributes that lead to group cohesion. The iconography of the means of settlement is mobilised in this respect (Image 1), while Rosario's crédito's does not carry any political meaning. It features the legend 'Banco Popular de la Buena Fe' ('Popular Bank of Good Faith'), Poriajhù's logo, and an ant. As the name of the main national microcredit program in which Poriajhú takes part, this first inscription implicitly associates the crédito to a wider political project. Poriajhú's logo consists of a daisy rooted in South America, some bricks, the organisation's name and the legend 'another world is possible' (otro mundo es posible). The daisy represents hope, its roots the (utopian) unity of South America, and the bricks the construction of the 'other South America', in keeping with the Poriajhú project. Meanwhile the ant symbolises group work and unity against possible enemies. By comparison, Rosario's crédito's almost does not carry any political meaning, beyond the reproduction of the monument that has been built in the honour of the creation of the Argentinian flag, located in that city. Finally in a speech given for the issuing of the new means of settlement (in September 2007), Marita sought to link the crédito to Poriajhú's political project, whilst comparing the crédito to the peso. She began by listing the peso's advantages: it enables one to have food, clothing, electric lighting, to use the telephone, etc. But she also presented the peso as a vehicle for vices such as organ selling, greed, injustice, poverty, power struggles, etc. She went on to say that it is the group's responsibility as a whole, in its daily use of the créditos, not to reproduce the peso's 'vices'.

\section{Insert here Image I}

Above all however, money plays a role in Poriajhú's political project through its relationship to debt. In Poriajhú, the prevailing modalities of access to the means of settlement underline a holistic representation of the relationships between the trueque participants and the political community in which the collective takes precedence over its parts. As mentioned in section 1, the crédito bills are distributed to each trueque participant before their first feria. In addition, their nominal value does not depend on the value of the goods offered at the trueque, but on their quality, as those offering self-produced commodities receive twice as many créditos that those who do not in order to encourage independence from clientelist relationships of the social assistance schemes. Furthermore, access to the means of settlement does not depend on individual circumstances, but on one's relationship to the group. Moreover, because trueque participants receive the means of settlement before getting involved in any transactions, it is the collective that enables trueque 
participation. Its participants are therefore indebted towards the collective, which underlines the political and holistic nature of Poriajhú's project.

In Rosario, the reverse is the case. To obtain the means of settlement (commodities or bills) one has to give up commodities or pesos (since 10 pesos can be exchanged for 8.000 créditos). But because this makes the group indebted to its members, individuals can more readily orchestrate it. It is thus much harder for the group to constitute itself beyond its diverse private interests than vice versa. Because the group is perceived as debtor towards trueque participants, it does not enjoy the necessary authority to impose monetary rules that would go against the individual interest of some of its members. In Rosario, no political project acts as mediation between the peso and the crédito sphere. In such conditions, any attempts to impose restrictions related to the way people juggle between crédito and peso would be considered as illegitimate.

\section{Conclusion}

This paper aimed at providing an original contribution to the institutionalist approach to money by addressing people's monetary practices, and by focusing on monies that differ from state and bank issued currencies. By so doing, its intention is to shift from the traditional sociological focus that conceives money as a social relation first and foremost through its relation to the State. In this perspective, it conceives money as a 'generic category' that 'must incorporate the full range of monetary forms that are in circulation today' (Dodd 2005: 572; see also Aglietta and Orléan 1998; Théret 2007) by considering créditos as monies in their own right, defined as systems of evaluation and settlement of debts. Considered in this way, money is a 'social relation' of credit/debt beyond the relation to banks and states implied by the dominant forms of currencies: as a social relation, it participates more fundamentally to the constitution of political communities that can be based on equal (Poriajhú) or on unequal basis (Rosario), by translating specific political projects in its institutions and monetary practices. This, in turn, reinforces institutionnalists' claim that money should not be considered as a by-product of market relations (see for instance Aglietta and Orléan 1998; Grierson 1978; Ingham 2004; Innes 2004 [1913]; Polanyi 1968 and Wray 1998: 39-73), as it refers to a more ambivalent kind of social relations, ranging from exploitation to the construction of new forms of solidarities.

While they are deeply embedded in the context of the trueque, these theoretical considerations also allow us to reconsider monetary transformations more broadly. In the early 2010s, the trueque 
almost disappeared, as the Argentinian peso became more widely used in the popular economy. Conventional interpretation would argue that this is due to the economy's recovering after the crisis, which allowed peso-denominated incomes to increase and the state to reinforce its capacity to impose taxation. However, the fact that the trueque remained an important element of the urban popular economy until the late 2000s despite the substantial economic growth of the 2003-2009 period casts doubts on this interpretation. I would argue that such transformation in monetary practices reveals a deeper transformation of the Argentinian society. On the one hand, the leftoriented Peronist government expanded the family allowances and minimum pensions to informal workers as a way to recognize the rights of the historically marginalized. Informal workers and their families now benefit from monthly incomes denominated in peso. On the other hand, "self-centred" growth policies based on domestic industrialization and wage increases have fuelled consumption, along side the consumer credit boom to non-registered workers. Therefore, the working class' wider access to the peso and subsequent abandon of the trueque are the results of a political process by which the urban subproletariat's rights and role as a consumer has been recognized. Beyond the Argentinian case, this argues in favour of considering the kinds of social transformations implied by monetary pluralism.

\section{Notes:}

\footnotetext{
${ }^{\mathrm{i}}$ The names of the places and those of the interviewees have been changed.

${ }^{\text {ii }}$ For the ethnographical records, see Drelon and de la Porte des Vaux (2007: 27:00-28:25; 28:50-30:03; 40:30-41:35).
} See REF ANONYM (2016: 107-110) for a more detailed analyse.

iii Table III has been elaborated on the basis of the arithmetic means of prices presented in table II.

iv The price of all the commodities offered is expressed in eggs. Eggs are always accepted as means of payment, but spices and vegetables can replace them in case of egg shortages (Drelon 2009: 220-9).

v Marita teaches at a local secondary school, and plays a key role in the Poriajhú. She gained great recognition throughout Rosario's industrial area, thanks to her militant actions in the field from the beginning of the 1980s.

${ }^{\text {vi }}$ For these authors, a reference to an authority is essential in order to establish a stable unit of account. While, Ingham (2006: 271) acknowledges that "other authorities [than States] can exist", he never gives concrete examples.

vii See Théret (2007) for examples of state-issued currencies rejected by their users because they were not considered legitimate.

viii See REF ANONYM (2016: 135-136) for more ethnographical details. 


\section{Tables and figures}

Table I: Summary of transactions between Eleonora, Stefani and Luis (Rosario)

\begin{tabular}{lr|l}
\multicolumn{2}{c|}{ Luis => Eleonora } & \multicolumn{2}{c}{ Eleonora => Lui } \\
Tomatoes (2Kg) & 5000 & Salt $(2$ packets $)$ \\
Courgettes (2) & 2000 & Sugar $(3 \mathrm{Kg})$ \\
Garlic (3 cloves) & 4500 & Soap $(1)$ \\
Apples (1Kg) & 2000 & Total before compensation \\
Mandarines (2kg) & 4000 & Sugar $(1 \mathrm{Kg})$ \\
Marrow (1) & 2500 & \\
Total & $\mathbf{2 0 0 0 0}$ & Total
\end{tabular}

\begin{tabular}{r|lr|ll} 
& \multicolumn{2}{|c|}{ Luis $=>$ Stefani } & \multicolumn{2}{c}{ Stefani => Luis } \\
2000 & Courgettes $(2$ & 1500 & Oil $(21)$ & 14500 \\
10500 & small $)$ & 5000 & & \\
4000 & Apples $(2 \mathrm{Kg})$ & Mandarines $(1 \mathrm{Kg})$ & 2000 & \\
16500 & Carrots $(1 \mathrm{Kg})$ & 1500 & \\
& Strawberries & & & \\
3500 & $(1 \mathrm{Kg})$ & 2000 & \\
& Tomatoes $(1 \mathrm{Kg})$ & 2500 & \\
$\mathbf{2 0 0 0 0}$ & Total & $\mathbf{1 4 5 0 0}$ Total & $\mathbf{1 4 5 0 0}$
\end{tabular}

Source: fieldwork

Table II: Price of groceries, Buenos Aires, 2006

\begin{tabular}{|c|c|c|c|c|c|}
\hline $\begin{array}{c}\text { Feria }=> \\
\text { Unit of account }=>\end{array}$ & 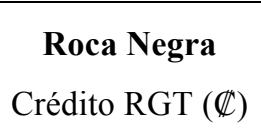 & $\begin{array}{c}\text { Aceitera } \\
\text { Crédito RGT }(\not \mathbb{C})\end{array}$ & $\begin{array}{c}\text { Quinta del } \\
\text { Pato } \\
\text { Eggs }(\mathrm{O})\end{array}$ & $\begin{array}{c}\text { Villa A. Brown } \\
\text { Used créditos }(\not \subset ’ ')\end{array}$ & Supermarket \\
\hline Pasta (500g) & 15000 & 18000 & 6 & 60 & $5 / 6$ \\
\hline Pasta plan ${ }^{1}$ & 10000 & 15000 & 6 & 60 & \\
\hline Rice (1kg) & 15000 & 18000 & 6 & 60 & $5 / 6$ \\
\hline Rice plan & 10000 & 10000 & 6 & 6 & \\
\hline Eggs (6) & 20000 & 25000 & $\mathrm{X}$ & No data & $3 / 4$ \\
\hline Dry milk (1kg) & 20000 & 22000 & 15 & 100 & 10 to $20 / 25$ \\
\hline $\begin{array}{l}\text { Dry milk plan } \\
(1 \mathrm{~kg})\end{array}$ & 18000 & 20000 & 15 & 100 & \\
\hline Flour $(1 \mathrm{~kg})$ & 8000 & 10000 & 10 & 60 & $3 / 4$ \\
\hline Flour plan (1kg) & 6000 & 8000 & 10 & 60 & \\
\hline Oil (11) & 25000 & 30000 & 30 & 150 & $4 / 5$ to 10 \\
\hline Oil plan (11) & 15000 & 20000 & 30 & No data & \\
\hline Oil (21) & 45000 & 50000 & No data & No data & $7 / 8$ to 20 \\
\hline Sugar $(1 \mathrm{~kg})$ & 18000 & 20000 & 10 & 80 & 2 to 5 \\
\hline Sugar plan (1kg) & 15000 & 18000 & 10 & 80 & \\
\hline Yerba mate $(1 \mathrm{~kg})$ & 15000 & 18000 & 6 & 60 & $7 / 8$ to 15 \\
\hline
\end{tabular}

Source: Drelon (2009: 222).

\footnotetext{
${ }^{1}$ Plan stands for social assistance in-kind subsidies.
} 